ACTA AGROBOTANICA

Vol. 59 z. 22006

s. 239251

Nieco uwag na temat astra chińskiego (Callistephus chinensis (L.)

Nees) ze szczególnym uwzględnieniem zmienności kwiatów

i kwiatostanów w świetle dotychczasowych opisów

\author{
ALICJA WOSIŃSKA \\ SGGW, Wydział Rolnictwa i Biologii, Katedra Fizjologii Roślin, \\ ul. Nowoursynowska 159, 02776 Warszawa \\ Warsaw Agricultural University, Faculty of Agronomy and Biology, \\ Department of Plant Physiology, Nowoursynowska 159, 02776 Warsaw
}

(Otrzymano: 20.12.2004)

\title{
Some notes on China aster (Callistephus chinensis (L.) Nees) with particular attention paid to the changeability of florets and inflorescences in view of the so far used descriptions
}

\section{$\mathrm{S}$ u m m a r y}

The paper is mostly devoted to the variability of florets and heads in Callistephus sp. in its wild form and cultivated varieties. Describing the variability of heads more attention was paid to florets and specially ray florets including rare and often incorrectly described florets with tubular corollas. Attention was called to the necessity of using univocal and generally accepted basic vocabulary for heterogamic heads.

Key words: China aster, head, flowers (florets)

\section{WSTEP}

Aster chiński (Callistephus chinensis (L.) Nees) jest jedynym gatunkiem rodzaju Callistephus (podplemię: Asterinae, plemię: Astereae, podrodzina: Asteroideae (Tubulifiorae), rodzina: Asteraceae (Compositae), rząd: Asterales (Synandrae).

Wspólną cechą rodziny Asteraceae jest wykształcanie swoistego typu kwiatostanu, zwanego koszyczkiem (calathium). Atrybutami koszyczka są: dno kwiatostanowe, otaczająca je okrywa zmodyfikowanych listków, kwiatki i występujące czasem przykwiatki.

Rodzina Asteraceae obejmuje dwie podrodziny Cichorioideae (Liguliflorae) i Asteroideae (Tubuliflorae).Zasadniczą cechą wyróżniającą obie podrodziny jest 
obecność lub brak kwiatów rurkowych. W podrodzinie Cichorioideae brak jest kwiatów rurkowych, wszystkie kwiaty w koszyczku są obupłciowe, o koronach języczkowatych, 5-ząbkowych. Koszyczki są homogamiczne. W podrodzinie Asteroideae w koszyczkach zawsze występują kwiaty o koronach rurkowatych lub rurkowatopodobnych (dzwonowatych, lejkowatych, rurkowato-nitkowatych) zwieńczone 5-ząbkowo, rzadziej korony ucięte. Koszyczki są homo lub heterogamiczne.

W koszyczkach homogamicznych (calathium homogamum) wszystkie kwiaty mają jednakową budowę organów reproduktywnych. Wielu autorów, za homogamiczne uważa koszyczki, które mają wszystkie kwiaty jednakowe, a równocześnie tylko obupłciowe.

W koszyczkach heterogamicznych (calathium heterogamum) występują kwiaty o niejednakowej budowie organów reproduktywnych, a mianowicie na brzegu koszyczka kwiaty są bezpłciowe lub słupkowe, a wewnątrz koszyczka obupłciowe lub pręcikowe. Korony tych kwiatów są zróżnicowane. Z porównania tego typu koszyczków do małego słoneczka dysk i odchodzące od niego promienie wywodzi się nazewnictwo.

W koszyczku wyróżnia się: (1) środek, czyli dysk (discus), stanowiący wewnętrzną cześć koszyczka, wypełniony prawie zawsze kwiatami rurkowymi, nazwanymi kwiatami dyskowymi (flores disci), (2) brzeg, albo promień (radius) czyli zewnętrzna część koszyczka, którą zajmują kwiaty nazwane promienistymi flores radii). Taki typ koszyczka nazwano calathium radiatum (za Ki rpicznikove m,1959).

Podane wyżej nazewnictwo jest też najczęściej stosowane i w literaturze anglojęzycznej (,disk floret”, ,ray floret” S u g d e n, 1992; Z o m 1 e f e r, 1994). Z o m le fer w obszernym opracowaniu botanicznym podaje, że nazwa „ray floret” jest zastrzeżona dla kwiatów o koronach „strape like” 2- lub 3-ząbkowych, nazwa zaś "ligulate floret" odnosi się do kwiatów doskonałych obupłciowych o koronach języczkowatych 5-ząbkowych.

Według dotychczasowych opisów (W i t , 1937; G o 1 u b k o v a ; 1959; F i s j u n,1965; R o s t a ń s k i 1971) koszyczki astra chińskiego są heterogamiczne (calathium heterogamum, typ c. radiatum). $\mathrm{Z}$ powodów wyżej motywowanych, za Kirpicznikovem (1959) i Z o m 1 e f e r (1994) przyjmuję zatem nazwy: (1) kwiaty dyskowe flores disci (synonimy: wewnętrzne, centralne, rurkowe) i (2) kwiaty promieniste flores radii (synonimy: brzeżne, zewnętrzne, peryferyczne, określane też po prostu opisowo jako kwiaty słupkowe, żeńskie, języczkowe, grzbieciste). Należy jednak wyraźnie podkreślić, że w takim odniesieniu nazwa „kwiaty promieniste" nie ma oczywiście nic wspólnego z ich symetrią, są to bowiem kwiaty przeważnie nibyjęzyczkowe o symetrii grzbiecistej.

Stosując u astra chińskiego w/w nazwy kwiatów będzie to kontynuowanie nazewnictwa używanego w opisach tego gatunku już przez W it a (1937). Nazewnictwo „disk florets”, „ray florets” jest też powszechnie stosowane w literaturze anglojęzycznej u gatunków roślin ozdobnych przez różnych autorów, np.: R a n a, 1964; Roderick i Cuming,1964; Gosling, 1973; de Jong i Drennman,1984. 
Klasyfikacje i nazewnictwo odnoszące się do odmian, stosowano na ogół, według zasad COBORU (A d l e r i in. 1976; A d l e r i in. 1980) opartych o system klasyfikacji odmian astra chińskiego Ma ats ch a i Schulze (1958), Nolthinga (1962) i Morgenthala (1969).

Spotykane często w literaturze hodowlanej, a nawet w podręcznikach akademickich, niepełność, niejasności lub wręcz błędy, w opisach kwiatów i koszyczków, a także nie przestrzeganie terminów botanicznych odnosi się to i do innych gatunków uprawnych $\mathrm{z}$ rodziny Asteraceae stanowiło motywację do podjęcia tematu, którego celem jest omówienie budowy i zmienności koszyczka astra chińskiego w świetle dotychczasowych opisów botanicznych, przy zastosowaniu jednoznacznego nazewnictwa. Temat ten, przez analogię, zasługuje tym bardziej na omówienie, że wśród uprawianych roślin ozdobnych jest wiele gatunków z rodziny Asteraceae, że wymienię tylko niektóre rodzaje: Chrysanthemum, Dendranthema, Dahlia, Aster, Zinnia, Bellis, Cosmos, Helichrysum, Tagetes i niektóre z nich, podobnie jak i Callistephus, odznaczają się ogromną skalą zmienności, a ich opisy i klasyfikacje także budzą zastrzeżenia.

\section{FORMA DZIKA}

Aster chiński jest endemitem na terenie Chin i Japonii (G o o d , 1947). Podawane przez niektórych autorów inne odległe miejscowości (wschodni Turkiestan, Afganistan, Tybet), nie są pewne, mogą to być miejsca dawnych, zdziczałych uprawza Wi te m (1937).

Dzika forma astra chińskiego, opisana przez H o o k e r a (1882, cyt. za W i t e $\mathrm{m}, 1937$ ) jest rośliną baldachowato rozgałęzioną, o pokroju rozpierzchłym, do 90 cm wysokości. Na końcach odgałęzień wyrastają pojedyncze koszyczki o średnicy 3,5 cala. Dno kwiatostanowe porowate, prawie gładkie. Dzwonowata okrywa koszyczka utworzona jest ze zróżnicowanych listków: zewnętrznych lancetowatych, zielonych, na brzegach plamisto wybarwionych antocyjanem na brązowo i listków wewnętrznych mniejszych, łuskowatych, tępych. Kwiaty promieniste żeńskie, mają korony języczkowate, fioletowe; zajmują 12 okółki. Kwiaty dyskowe; obupłciowe, o koronach rurkowatych, złotożółtych, krótkich, 5-ząbkowych. Słupek zakończony dwudzielnym znamieniem. Wszystkie kwiaty w koszyczku są płodne. Owocki jajowate wydłużone, pokryte białymi włoskami, u nasady otoczone białym puchem szczecinek kielicha.

Sprawdzenie podanego przez $\mathrm{H}$ o o k e r a opisu, jest co najmniej utrudnione. Nechansky i Jir ase k (1967) podają w wątpliwość występowanie współcześnie dzikiej formy astra chińskiego. Nasiona, które autorzy otrzymali z Ogrodu Botanicznego w Pekinie, nie kiełkowały, a pisemne zapytania do niektórych Ogrodów Botanicznych we Wschodniej Azji zostawały bez odpowiedzi. Autorka niniejszej pracy, również usiłowała uzyskać nasiona dzikiej formy. Niestety, na kilkanaście wysłanych listów do Ogrodów Botanicznych w Azji i Europie, uzyskano tylko jedną przesyłkę roślin i nasion z Ogrodu Botanicznego w Meise (Belgia). Koszyczki tej formy różniły się od opisu $\mathrm{H}$ o o k e r a barwą były jasno różowe, a pędy i liście nie były wybarwione antocyjanem. 


\section{ODMIANY HODOWLANE}

Aster chiński sprowadzono do Europy w latach 1728-1731. Przypuszcza się, że przywiezione rośliny były już formami uprawnymi (W i t, 1937; N e c h a n s k y i J i r a s e k, 1967). Callistephus wzbudził od razu zainteresowanie hodowców i wkrótce stał się jedną z najbardziej popularnych, jednorocznych roślin ozdobnych. Możliwość uzyskiwania nowej zmienności, w tym tak bardzo ważnej u roślin ozdobnych, bo dotyczącej kwiatostanu, okazała się ogromna. Już bowiem w 1865 r. na wystawie w Erfurcie przedstawiono 280 odmian tego gatunku. Dalsze prace hodowlane zwiększały liczbę odmian. Obecnie w światowym asortymencie jest ok. 600 odmian, wśród których wydzielono 40 grup różniących się wysokością, pokrojem i krzewiastością roślin oraz wielkością, formą, budową i barwą koszyczków (P e t r e n k o , 1972).

Monograficznego opracowania $\mathrm{w}$ języku polskim aster chiński jeszcze się nie doczekał. Opisy polskich odmian, których w 2000 r. było 102, w tym 92 odmiany oryginalne (Praca Zbiorowa, 2000) znaleźć można w Informatorach COBORU. Opisy te są, niestety, czasem błędne. Z opracowań zagranicznych należy wymienić dokładne opisy i obszerne badania Wit a (1937), pracę Nechansky i Jir a s e k (1967) oraz cenną pracę Pr u ch o v ej (1970). W tej ostatniej dano opisy 404 odmian, uzupełnione licznymi ilustracjami. Wymienić należy również pracę P e t r e n k i (1972), w której podjęto próbę jeszcze jednej klasyfikacji astrów, oraz obszerną pracę W o l k o v e j (1983), w której m.in. przedstawiono listę 162 odmian i podano opisy niektórych $\mathrm{z}$ nich.

\section{Elementy składowe koszyczka}

Elementy składowe koszyczka stanowią: okrywa, dno kwiatostanowe i gęsto ułożone kwiaty. Schemat budowy koszyczka uwidacznia ryc. 1.

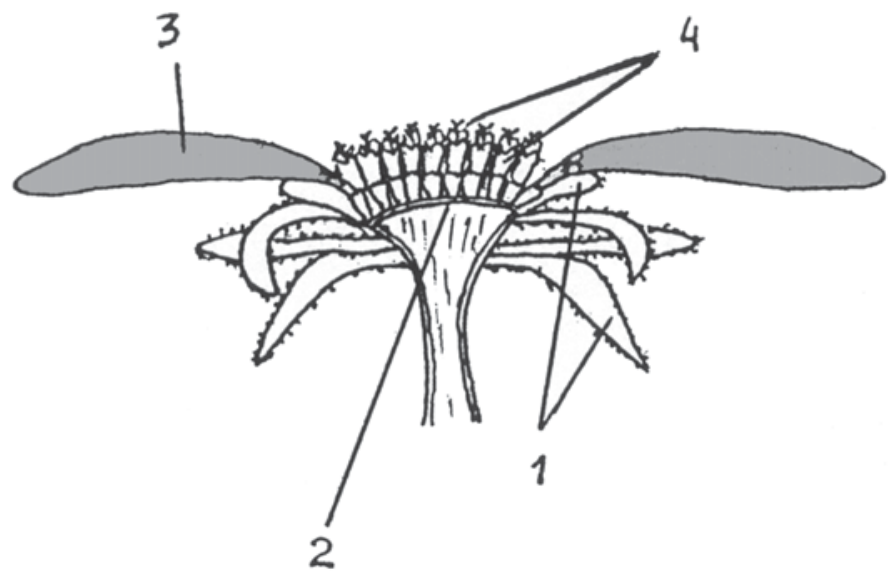

Ryc. 1. Callistephus chinensis schemat budowy koszyczka l listki okrywy; 2 dno kwiatosta nowe (receptaculum); 3 kwiaty promieniste (flores radii); 4 kwiaty dyskowe (flores disci).

Fig. 1. Callistephus chinensis a diagram of head structure: 1 involucre bracks; 2 receptacle; 3 ray florets; 4 disc florets. 
Okrywa (involucrum). Okrywę koszyczka tworzy kilka szeregów zróżnicowanych listków. Listki z zewnętrznych szeregów są normalnie wybarwione, łopatkowato-lancetowate, o brzegach nieco orzęsionych. Listki z dwóch szeregów wewnętrznych, przylegających do kwiatów promienistych, są mniejsze, szeroko języczkowate, pergaminowate, siatkowato unerwione, u góry słabo wybarwione w odcieniu kwiatów promienistych (G o ł u b k o v a , 1959; F i s j u n , 1965; P o li a k o v, 1967; R o s t a ń s k i , 1971). Graniczne wielkości listków według G o ł u b k o v e j (1959) wynoszą: zewnętrzne dł. 0,8-3 cm, szer. 0,5-0,8 cm, a listków wewnętrznych odpowiednio $0,7-1,3 \mathrm{~cm}$ i $0,3-0,6 \mathrm{~cm}$.

Dno kwiatostanowe (receptaculum) w koszyczkach astra chińskiego jest płaskie albo lekko wypukłe, porowate (Wi t, 1937; G o łu bkova, 1959; F i s ju n, 1965; P e tre n k o, 1972;). K u ku łc z a n ka (1965) opisała i przedstawiła dokumentację fotograficzną występowania u Callistephus dna kwiatostanowego z plewinkami. Autorka niniejszej pracy, także obserwowała u różnych odmian i w materiałach własnych występowanie plewinek, analogicznych do wyżej opisanych (Wo s i ń s k a , dane nie publikowane). Ku kułc z a n k a uważa, że występowanie plewinek jest cechą dziedziczną, podlegającą dużym modyfikacjom, ich obfitość uzależniona jest od nawożenia.

Kwiaty. W koszyczkach astra chińskiego występują dwa rodzaje, morfologicznie zróżnicowanych kwiatów. Są to: kwiaty promieniste żeńskie i kwiaty dyskowe- obupłciowe (W i t, 1937; G o ł u b k o v a , 1959; F i s j u n, 1965; P o l i a k o v, 1967). Spotykane u astra chińskiego formy kwiatów dyskowych i niektórych promienistych obrazuje ryc. 2.

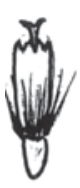

1

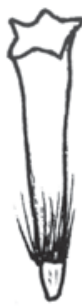

2

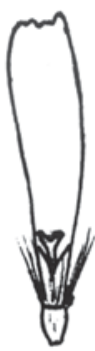

3

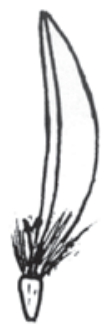

4

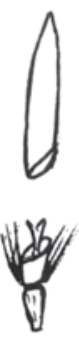

5
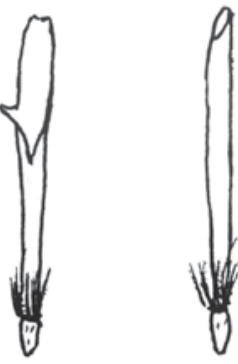

6
7

Ryc. 2. Typy koron kwiatów dyskowych (1 2) i kwiatów promienistych (3 7): 1 korona perga minowata krótka, 2 barwna, wydłużona: 3 korona języczkowata, płaska; 4 języczko wata, łódeczkowata; 5 rurkowata całkowicie zrośnięta; 6, 7 częściowo zrośnięte w rurkę (rurkowo języczkowate).

Fig. 2. Type of corollas of disc florets ( 12 2) and type of corollas of ray florets (3 7 ): 1 parchment like corollas, short; 2 coloured, elongualed; 3 ligulated, flat; 4 ligulated, boat shaped; 5 tubular, fully closed tube; 67 tubular ligulated (corolla splitting). 
K w i a t y d y s k o we (flores disci) mają korony rurkowate, mało zróżnicowane, w czasie kwitnienia otwierają się 5-ząbkowo (W it, 1937; P ol i a k o v, 1967; R o s t a ń s k i , 1971; W ołk o v a , 1983). Barwa i długość koron u odmian jest różna. U większości odmian korony są krótkie do $0,5 \mathrm{~cm}$, pergaminowate żółtą barwę nadają im wypełnione obficie pyłkiem pylniki. U małej grupy odmian (astry Książęce) korony kwiatów są silnie wydłużone, nawet do długości kwiatów promienistych, i są jak one wybarwione. Cecha ta jest uwarunkowana genem T. Jest to gen labilny, powodujący, że nie we wszystkich koszyczkach kwiaty są w jednakowym stopniu wydłużone. Allel t tego genu powoduje, że kwiaty dyskowe są krótkie, pergaminowate (W i t, 1937). Kwiaty dyskowe są zawsze obupłciowe. Według dotychczasowych opisów (W i t, 1937; G o ł u b k o v a , 1959; F i s j u n , 1965; P o li a k o v, 1967; R o s t a ń s k i , 1971; W ołk o va , 1983) są to kwiaty 5-krotne, o pięciu pręcikach przymocowanych wolnymi nitkami do rurki korony. Pylniki są wydłużone, u góry z tępo trójkątnym przydatkiem, brzegami spojone, tworzą tzw. rurkę pylnikową, otaczającą szyjkę słupka.

K w i a t y p r o m i e n i s t e (flores radii) opisywane są jako kwiaty żeńskie (Wi t , 1937; G o ł u b k ov a, 1959; R os tań s ki , 1971; P e tren k o, 1983), mają korony języczkowate, na szczycie całobrzegie lub krótko 2-ząbkowe (F i s j u n , 1965; P o l i a k o v , 1967), różnej długości i szerokości według R o s t a ń s k i e g o (1971): dł. 3-5 cm, a szer. 0,3-1 cm, zaś według P e t r e n k o (1983): dł. 1-6 cm, a szer. 0.3-1 cm. W ołkova (1983) podaje, że na szczycie korony są 3 ząbki, odpowiadające trzem zrosłym płatkom.

Kwiaty promieniste cechuje ogromna skala zmienności koron, dotyczy to ich wielkości (długości i szerokości), sztywności, barwy i kształtu. W większości są to korony języczkowate, zróżnicowane pod względem formy, i stąd wywodzą się często ich nazwy, np.: tasiemkowate, łyżeczkowate, łódeczkowate, igiełkowe.

Oprócz kwiatów o koronach języczkowatych, są wzmianki i o koronach rurkowatych (Ma at sch i Schulze, 1958; Morgenthal, 1969; Petrenko, 1972; W o ł k o va ,1983), brak jest jednak dokładnych opisów tych kwiatów. W ołk o v a (1983) wprawdzie pisze o nich w sposób wyraźny, że są one zrośnięte w rurkę, ale zalicza je błędnie do kwiatów igiełkowych. Także niektóre polskie odmiany np. 'Srebrzysta Gwiazdka' i 'Roma' mają kwiaty promieniste o koronach rurkowatych, ale są błędnie opisywane i zaliczane do astrów promienistych (A d le r i in. 1983) lub igiełkowych (K o r o h o d a , 1972). Autorka niniejszego opracowania, uzyskała w doświadczeniach własnych kilkadziesiąt linii z takimi kwiatami promienistymi (Wo s i ń s k a , 1984,1998 i dane nie publikowane). Korony tych kwiatów mają kształt zamkniętej rurki i w przeciwieństwie do kwiatów dyskowych nie otwierają się, podobnie jak u $c v$ 'Roma' i 'Srebrzysta Gwiazdka'. Kwiaty o tego typu koronach przedstawia ryc. 2, a koszyczek $\mathrm{z}$ takim kwiatami ryc. 5. Kwiaty te, podobnie jak kwiaty o koronach języczkowatych, cechuje duży zakres zmienności, także i pod względem barwy.

Oprócz kwiatów promienistych o koronach rurkowatych zamkniętych, występują u roślin niestabilnych genetycznie kwiaty promieniste o koronach rurkowojęzyczkowatych (Wo s ińs k a , 1982, 1984, a także dane nie publikowane). Barwna korona tych kwiatów jest w różnym stopniu zrośnięta w rurkę. Ten typ koron widoczny jest na ryc. 2 . 
B u d o w a $\mathbf{k}$ w i a t ó w. Z charakteru kwiatów wynika, że słupki występują i w kwiatach dyskowych i promienistych. Słupek jest dolny, jednokomorowy, z jednym zalążkiem. Szyjka słupka zakończona jest dwułatkowym znamieniem na szczycie z płonym przydatkiem, poniżej, po obu stronach z powierzchnią znamionową (G o ł u b k o v a, 1959). P o li a k ov (1967) pisze, że w kwiatach promienistych łatki znamion słupka są na brzegu krótko orzęsione i bez przydatków, a w dyskowych na szczycie występują tępokątne przydatki, pokryte gęsto frędzlowatymi wypustkami. Wó y ci c ki (1969) podaje, że płodny jest tylko brzeg znamienia, nie zaznacza jednak, czy odnosi się to do kwiatów promienistych czy dyskowych. Ponieważ wszystkie kwiaty w koszyczku są płodne, można sądzić, że odnosi się to do wszystkich kwiatów.

W kwiatach dyskowych i promienistych kielich wykształcony jest jako tzw. pappus i jest 2-szeregowy: zewnętrzny w postaci krótkiego rąbka, złożonego ze zrośniętych nasadami szczecinek, zaś wewnętrzny stanowią białe, ok. $5 \mathrm{~mm}$ długości szczecinki G ołu b k ova, 1959; R os t a ń s ki , 1971).

\section{Zmienność koszyczków}

O wyglądzie koszyczków stanowią wszystkie jego elementy, a nade wszystko kwiaty ich liczba, barwa, wielkość, kształt i układające się proporcje między kwiatami dyskowymi a promienistymi.

Liczba kwiatów w koszyczkach u różnych odmian jest różna. Podany przez R o st a ń s ki e g o (1971) zakres liczby kwiatów w koszyczkach 40-160, nie jest słuszny, są to bowiem wartości prawdopodobne dla koszyczków niewielkich. Podane przez K u ku ł c zan k ę $(1961,1965)$ wyniki z obserwacji liczby kwiatów w koszyczkach astrów Książęcych: 335-1270 i astrów Igiełkowych: ok. 250-1160, dają pewną orientację o liczbie kwiatów u odmian o koszyczkach dużych.

Obserwowany u astra chińskiego zakres barw kwiatów jest bardzo szeroki - od barwy białej, poprzez różne odcienie różu, do czerwonej, poprzez jasno fioletową, do prawie czarnej; występują też odcienie barwy żółtej i łososiowej. W literaturze omawiającej obszernie aster chiński zarówno wśród polskich odmian (A d l e r i in.1976; Korohoda, 1972) jak i wśród zagranicznych (N e c h a n s k y i in.1967; P e t r e n k o, 1972; W o 1 k o v a, 1983) nie ma wzmianek o kwiatach promienistych 2-barwnych. Również P r u c h o v a (1970), opisując badane przez siebie 404 odmiany, nie wymienia żadnej o tego rodzaju kwiatach, przy omawianiu historii hodowli astra chińskiego, podaje jednak, że w cenniku firmy Mette, Quedlinburg z 1926-1927 r., w niektórych grupach astrów były odmiany o kwiatach promienistych dwubarwnych - $\mathrm{z}$ białym środkiem, $\mathrm{z}$ białymi końcami albo z białymi prążkami. Autorka niniejszej pracy uzyskała mutację dwubarwności języczkowatej korony kwiatów promienistych (Wo s i ń s k a , 1984) i aktualnie jest to jedyna forma 2-barwności.

Ze względu na występowanie w koszyczkach alternatywnie dwóch rodzajów kwiatów dyskowych, koszyczki mogą być homo- lub heterochromatyczne. Koszyczki homochromatyczne występują u stosunkowo niewielkiej grupy odmian, określanych jako astry Książęce (Koronowe). Jeden tego typu koszyczek przedstawia ryc. 3. Astry o takich koszyczkach pojawiły się już w końcu XVIII w. i otrzymały nawet nazwę Aster fistulosus (W i t, 1937). W ostatnich latach liczba odmian w tej grupie 


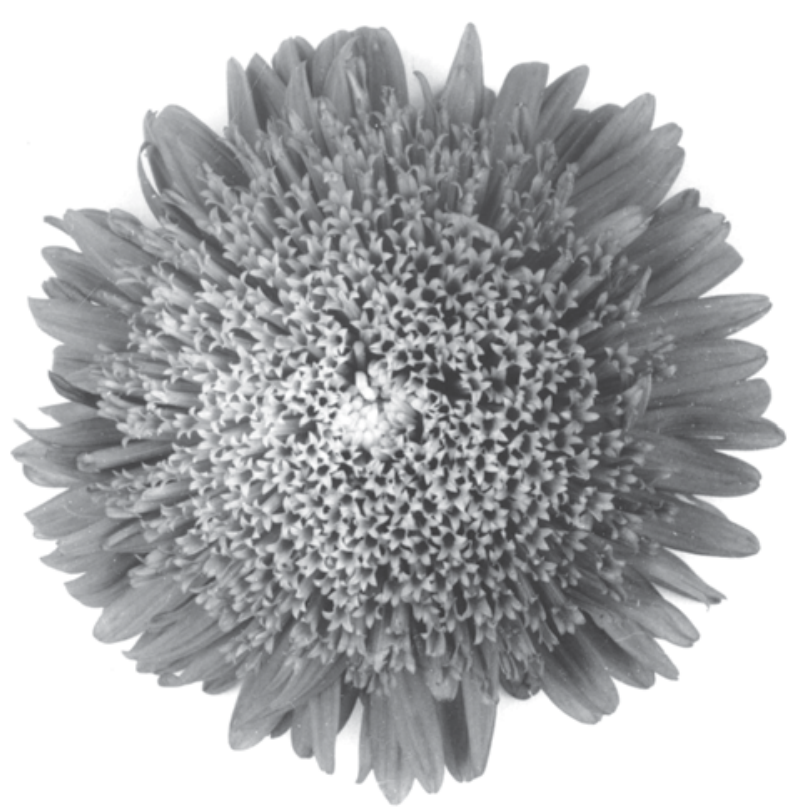

Ryc. 3. Callistephus chinensis, koszyczek homochromatyczny (grupa Prinzess typ Regulares).

Fig. 3. Callistephus chinensis homochromatic head (group Princess, type Regulares).

szybko wzrasta, aczkolwiek w porównaniu do poprzedniej, jest znacznie mniej liczna. P r u c h o v a (1970) na 404 opisywane odmiany, wymienia z tej grupy tylko 143. W Polsce, do 1976 r. była tylko jedna odmiana tego typu (A d l e r i Z a ł ę s k a, 1976), a obecnie jest 11:8 odmian oryginalnych i 3 selekcjonowane ( $\mathrm{P} \mathrm{r}$ a c a $\mathrm{Z}$ b i o r o w a, 2000).

W grupie astrów heterochromatycznych, u których występują opisane już kwiaty dyskowe o koronach pergaminowatych, krótkich, dekoracyjność koszyczków zależy przede wszystkim od kwiatów promienistych i od liczby okółków zajmowanych przez te kwiaty. Jedną z cech koszyczka w tej grupie odmian jest jego tzw. pełność, czyli układające się proporcje między kwiatami dyskowymi a promienistymi. Wyróżnia się trzy typy pełności koszyczków (M a a s c h i S c hulze, 1958 i wszystkie późniejsze klasyfikacje), a mianowicie:

1) pojedyncze (Simplices) kwiaty promieniste wypełniają 1-2 okółki,

2) półpełne (Semipleni\} kwiaty promieniste wypełniają kilka okółków,

3) pełne (Pleni) kwiaty promieniste występują w licznych okółkach i osłaniają kwiaty dyskowe.

Wymienione typy koszyczków uwidacznia ryc. 4.

P e t r e n k o $(1972,1983)$ wyróżnia jeszcze czwarty typ pełności koszyczki bardzo pełne. Jest to odpowiednik typu Pleni, z zaznaczeniem, że kwiaty dyskowe osłonięte są do końca kwitnienia. 
1

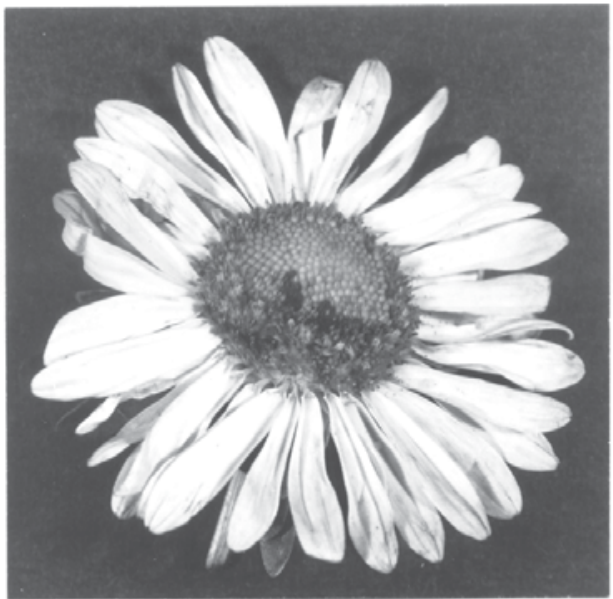

2

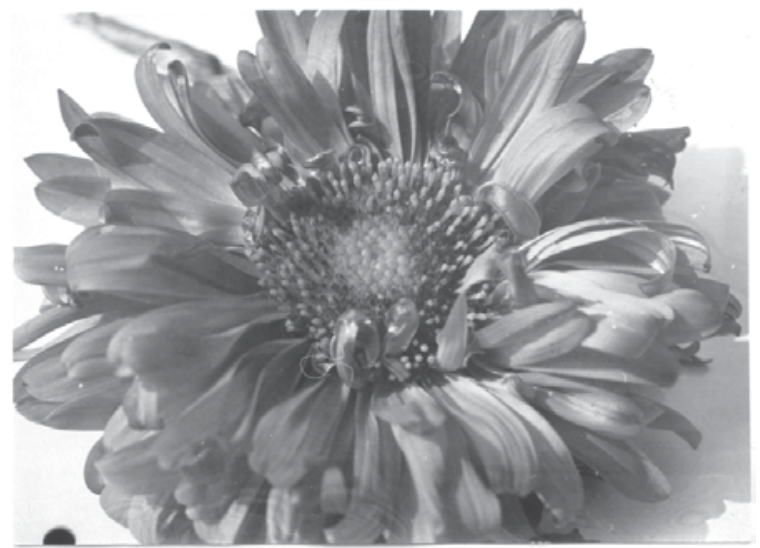

3

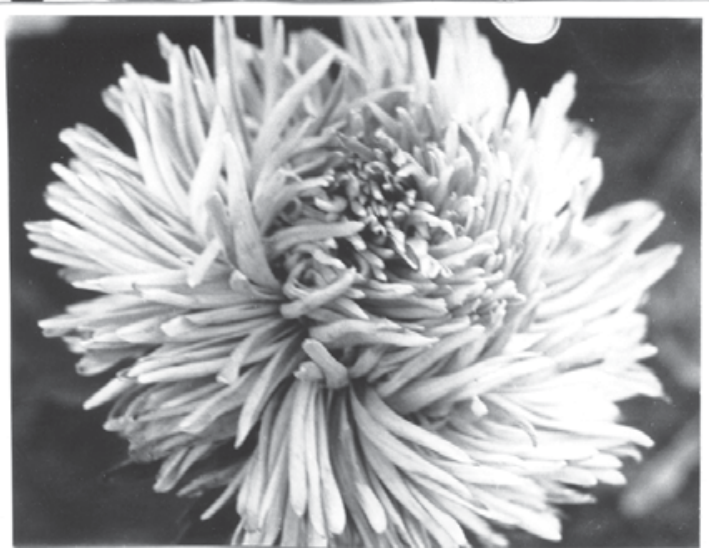

Ryc. 4. Typy pełności koszyczków heterochromatycznych: 1 koszyczek pojedynczy (Simplices), 2 koszyczek półpełny (Semipleni), 3 koszyczek pełny (Pleni).

Fig. 4. Types of doubleness of heterochromatic heads: 1 single (Simplices); 2 Semidouble (Semipleni); 3 double(Pleni). 
1

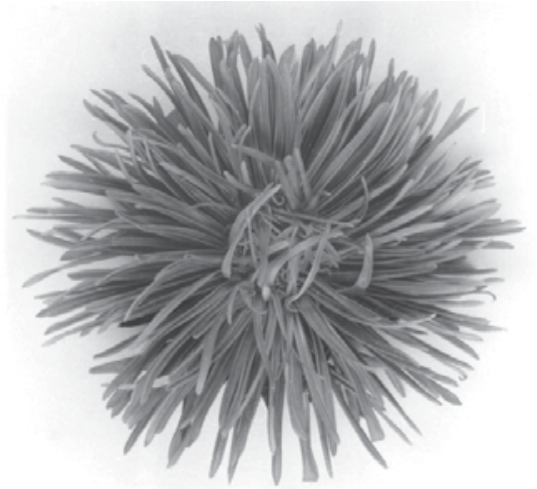

2

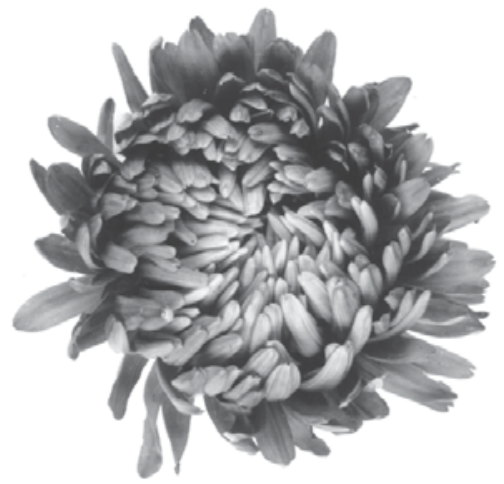

3

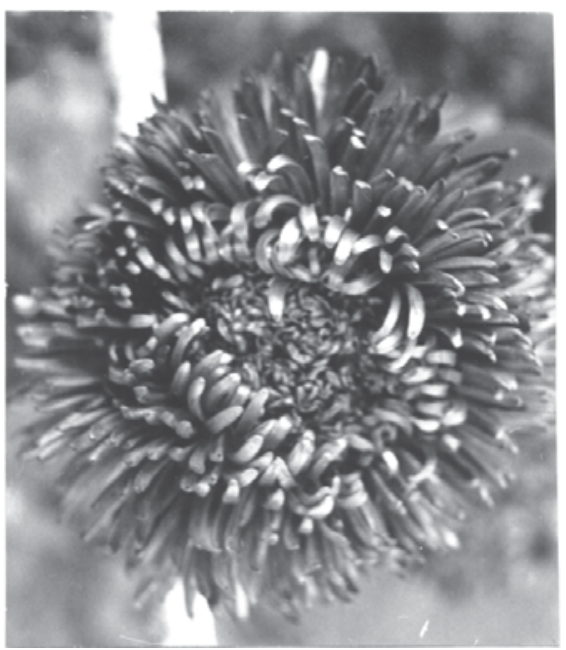

Ryc. 5. Niektóre typy koszyczków Callistephus chinensis: 1 igiełkowy (Recti), 2 kulisty (Sphaericum), 3 rurkowy (Clausitubulati)

Fig. 5. Callistephus chinensis some types of heads: 1 rayonant (Recti); 2 spherical (Sphaeri cum); 3 tubular(Clausitubulati). 
Omówione już wyżej koszyczki homochromatyczne (astry Książęce), uznawane są za pełne, mimo iż większość okółków wypełniają kwiaty dyskowe, jest to zatem przynależność umowna, botanicznie bowiem odpowiadają typowi Simplices lub $\mathrm{Se}$ mipleni.

W dotychczasowych klasyfikacjach odmian, jednym z zasadniczych kryteriów podziału jest typ koszyczka. W klasyfikacji M a a t s c h a i S c h u l z e (1958), uzupełnionej przez N o l t h in g (1962) i M o r g e n t h a 1 a (1969), a polecanej w Polsce przez COBORU (A d l e r i in. 1976, 1980) w obrębie odmian hodowlanych wydzielono trzy Klasy: Tubi-, Inaequi- i Liguliformes, obejmujących łącznie 14 typów koszyczków. Za kryterium podziału przyjęto formę kwiatów, ich sposób ułożenia oraz pełność i wygląd koszyczka. Niektóre typy koszyczków uwidacznia ryc. 3, 4, 5.

W Klasie Tubiformes wydzielono tylko jeden typ koszyczka Clausitubulati. Cechą charakterystyczną tych koszyczków są kwiaty promieniste o koronach rurkowatych. Stawiane przez w/w autorów mało precyzyjne kryterium i niejednoznaczne nazewnictwo, przy klasyfikowaniu takich odmian stanowi trudność nawet dla specjalistów, świadczy o tym przykład $c v$ 'Stephan Lochner'. Koszyczki tej odmiany podawane są jako wzór dla typu Clausitubulati (M a a t s c h i S c h u 1 z e, 1958) a Pruchova (1970) zalicza je do typu Transientes. Jak już wspomniano, kilka polskich odmian m.in. 'Roma' i 'Srebrzysta Gwiazdka', spełnia kryteria przynależności do Clausitubulati, a są błędnie opisane i zaliczane do Radiati (A d le r i in. 1976) lub do Recti (K or o hod a , 1972). Liczba odmian w Klasie Tubiformes jest niewielka. Pruchova (1970) w badanej kolekcji stwierdziła 4 odmiany o tego typu koszyczkach, a Petrenko (1972) dwie.

W Klasie Inaequiformes jest 5 typów koszyczków: wydzielonych według pełności (Simplices i Semipleni) i według kwiatów dyskowych (astry Książęce- Multiseriati, Regulares $i$ Transientes $\mathrm{M}$ a a t s ch i S ch u l z e, 1958).

W Klasie Liguliformes wyróżniono 8 typów koszyczków, wszystkie z grupy Pleni. O ich dekoracyjności stanowią zatem kwiaty promieniste, korony tych kwiatów są języczkowate $\mathrm{i}$ one ich forma i wygląd stanowią kryterium podziału. Wyróżnia się następujące typy koszyczków: Recurvi (rzemykowate), Inflexi (pazurkowate), Recti (igiełkowe), Radiati (promieniste), Imbricati (dachówkowate), Subconvexum (łyżeczkowate), Sphaericum (kuliste) i Laxiflorum (,balet”), niektóre z nich uwidacznia ryc. 5. Niektórzy autorzy (P e tr e n k o , 1972; W o ł k o v a, 1983) podają, że w koszyczkach typu Recti korony języczkowate są zwinięte w rurkę i zrośnięte. Jeszcze raz świadczy to o niejednoznaczności opisów i trudnościach w klasyfikacji.

Zmienność koszyczków, to także rozmaita ich wielkość. Zależnie od odmiany średnica koszyczków wynosi 2-16 cm (W o ł k o v a, 1983). Podane przez R o s t a ń s ki e g o (1971) średnice koszyczków odmian hodowlanych 7-16 cm, nie uwzględniają odmian o koszyczkach drobnych, np. astrów z grupy Petita. Na roślinie koszyczki największe są na pędzie głównym i na odgałęzieniach 1-go rzędu.

Ze względu na charakter pracy, omówiony zakres zmienności jest oczywiście niepełny. Skalę zmienności w obrębie Callistephus sp. obrazuje lista istniejących i stale powstających odmian. Równolegle z pracami hodowlanymi, nie postępuje niestety, teoretyczne opracowanie gatunku. W opisach odmian zwraca się uwagę na cechy ważne w uprawie i hodowli pomijając cechy botanicznie istotne. $\mathrm{Z}$ tych powodów 
gatunek ten oczekuje na dobre opracowanie botaniczne, a także wymaga rewizji opisów aktualnych odmian i ich uzupełnienia. Opracowanie genetyczne astra chińskiego jest także zaledwie zapoczątkowane. Wymaganiem zasadniczym jest także stosowanie poprawnego i jednoznacznego nazewnictwa. Dopóki te warunki nie będą spełnione, dopóty nie będzie możliwe opracowanie czytelnej, opartej na cechach botanicznie istotnych klasyfikacji istniejących odmian.

\section{LITERATURA}

A d l e r J., D u b a s G. W iśn i e w s k i J., 1983. Charakterystyka odmian. Rośliny ozdobne. COBORU, Słupia Wielka.

A d l e r J., J a nk ow sk a K., W i śn i ew ski J., Z a ł ę s k a M., 1980. Metodyka doświadczeń z odmianami roślin ozdobnych. T. I, Cz. II. Metodyka szczegółowa. COBORU „Słupia Wielka.

Adler J., Załęsk a M., 1976. Polskie odmiany roślin ozdobnych. Aster chiński Callistephus chinensis (L.) Nees. Informator COBORU (2) 66, Słupia Wielka.

F i s j u n W. W., 1965. Kallistefus Callistephus Cass. [In:] Flora Kazachstana, t. 8. B. Pawłov (ed.), Izd. Nauka, Ałma Ata, pp.312 314.

G o ł u b k o v a W. F., 1959. Rod Kallistefus Callistephus Cass. [In:] Flora SSSR, t. 25. B.K. Šiškin (ed.), Izd. Akademii Nauk SSSR, Moskwa, Leningrad, pp. 7377.

G o o d R., 1947. The geography of the flowering plants. London New York.

Gosling S., 1973. The Pocked Encyklopedia of Chrysanthemums in Color, Arco Publishing Company, Inc., New York.

K o r o h o d a J. (red.) 1972., Produkcja nasion roślin ozdobnych. PWRiL, Warszawa.

De Jong J., Drennan D. L.,1984. Genetic analysis in Chrysanthemum morifolium. II. Flo wer doubleness and ray floret corolla splitting. Euphytica, 33: 465470.

K irpicznikov M. E., 1959. Sem. CLX. Słożnocvetnye Compositae P. F. Gmelin. [In:] Flora SSSR, t. 25. B. K. Šiškin (ed.), Izd. Akademii Nauk SSSR, Moskwa Leningrad, pp. 117.

K u k u $\nmid$ c z a n k a K., 1961. Morfologiczne pokrewieństwo odmian Callistephus chinensis rasy Princess. Acta Agrobot. 10 (1): 185197.

K u k u ł c z a n k a K., 1965. Zmiany modyfikacyjne morfologii astra chińskiego (Callistephus chinensis Nees) pod wpływem działania azotu, potasu i fosforu, Acta Univ.Wratisla viensis 33, Pr. Bot. 5, PWN, Oddz. Wrocławski.

Ma at s ch R., Schulze G., 1958. Versuch einer typenmasigen Gliederung der Körbchen und Blütenformen gartnerisch wichtiger Compositae und ihrer Kulturformen. Gartenbau wissenschaft, 23: 160166.

Morgenthal J., 1969. Sommerblumen. BLV. München.

Nechan s k y F., Jir a s e k V., 1967. Systematische Studie (über kultivierte Sommerastern (Gartenastern) Callistephus chinensis (L.) Nees (Asteraceae). Preslia (Praha), 39: 122150.

N o 1 th i n g G., 1962. Das Sommerastern Sortiment. Gartenwelt Hort. Aster, 3 (32): 5253.

Pe tre n k o N. A., 1972. Klasyfikacja astry kitajskoj. Trudy po Prikladnoj Bot. Genet. i Selekcji, 46 (2): 278290.

P e t r e $n$ k o N. A., 1983. Astra odnoletnjaja. [In:] Ł. A. Kitaeva (ed.). Semenovodstvo cvetocznych kultur. Rosselchozizdat, Moskwa: 4955. 
Poli a k ov P. P., 1967. Sistiematika i proischożdienije słożnocvetnych. Izd. Nauka Kazachskoj SSR, Ałma Ata.

P r a c a Z b i o r o w a, 2000. Lista odmian roślin ozdobnych, COBORU, Słupia Wielka.

Pruchova A., 1970. Libochovicky sortiment cinskych aster Callistephus chinensis Nees. Separatni Vytisk, Vedecke Prace Vyzkumneho Ustavu Okrasn. Zahrad. V Pruchonicich, 5: 207260.

R a n R. S., 1965. Radiation induced variation in ray floret characteristic of annual chrysanthe mum. 14: 296300.

R o d e ri ck W., C u m ming, 1964. The chrysanthemum book, D.Von Nostrand Company, INC., Princeton, New Jersey, Toronto, New York, London.

R o s t a ń s ki K., 1971. Callistephus Cass. [W:] Flora Polska, t. 12. B. Pawłowski, A. Jasiewicz (red.), PWN, Warszawa, Kraków, pp. 121123.

S u g d e n A., 1992. Ilustrowany Słownik Botniczny. Zakł. Nar. im. Ossolińskich, Wydawnic two Wrocław Kraków.

W it F., 1937. Contributions to Genetics of the China aster. Genetica ,19: 2104.

W o ł k o v a G. A., 1983. Odnoletniaja astra w usłovijach Komi ASSR, Nauka, Leningrad

W o s ińska A., 1976. Wpływ różnych dawek promieni gamma na aster chiński (Callistephus chinensis (L.) Nees). Praca doktorska, SGGW AR, Warszawa.

Wosińska A., 1982. V. Indukowanie promieniami gamma ${ }^{60}$ Co zmienności modyfikacyjnej i mutacji u astra chińskiego (Callistephus chinensis (L.) Nees). Acta Agrobot. 35: 285301.

W o s i ń s k a A., 1984. Radiomutant dwubarwności kwiatów języczkowych uzyskany u astra chińskiego (Callistephus chinensis (L.) Nees) z odmiany 'Dukat'. Acta Agrobot. 37 (2): 117121.

Wosińska A., 1998. Mutacja spontaniczna w kolekcji radiomutantów astra chińskiego (Callistephus chinensis (L.) Nees). Zesz. Probl. Post. Nauk Rol. 463: 649660.

W ó y c i c k i S., 1969. Zarys hodowli roślin ozdobnych, PWRiL, Warszawa.

Zomle fer W. B., 1994. Guide to flowering plant families, The University of North Carolina Press, Chapel. Hill \& London.

\section{Streszczenie}

Praca dotyczy przede wszystkim zmienności kwiatów i koszyczków u Callistephus sp. u dzikiej formy i odmian hodowlanych. Opisując zmienność koszyczków poświęcono więcej miejsca kwiatom, a szczególnie kwiatom promienistym, w tym rzadziej spotykanym i często błędnie opisywanym kwiatom o koronach rurkowatych.

Zwrócono uwagę na konieczność stosowania jednoznacznego i ogólnie przyjętego dla koszyczków heterogamicznych podstawowego nazewnictwa. 
